\title{
Consumer preferences of apples in Estonia and changes in attitudes over five years
}

\author{
Ulvi Moor ${ }^{1 *}$, Argo Moor ${ }^{2}$, Priit Põldma ${ }^{1}$ and Lagle Heinmaa ${ }^{1}$ \\ ${ }^{1}$ Institute of Agricultural and Environmental Sciences, Estonian University of Life Sciences, Kreutzwaldi 1, 5104 Tartu, Estonia \\ ${ }^{2}$ Institute of Economics and Social Sciences, Estonian University of Life Sciences, Kreutzwaldi 1, 5104 Tartu, Estonia \\ e-mail: ulvi.moor@emu.ee
}

\begin{abstract}
Apple preferences of Estonian consumers ( $n=336$ in 2007 and 332 in 2012) were determined regarding apple origin, production method and different quality attributes. The aim was to find out whether apple preferences of young people raised in a capitalistic system differ from older people raised in the Soviet Union and also to determine if and how these preferences have changed over five years. The majority of the respondents preferred domestic apples ( $91 \%$ and $81 \%$ in 2007 and 2012, respectively), the main motivation being food safety: domestic apples were believed to contain fewer chemical residues. Apple taste was the most important quality attribute, followed by appearance which was rated equally important as health benefits and finally, price. Young people ( $<25$ years) were significantly more indifferent towards apple origin compared to others. However, the preference for apple taste and colour was similar in all age groups. Over the five year period surveyed, the preference for domestic and organic apples had decreased, but taste and colour preference had remained unchanged.
\end{abstract}

Key words: local foods, organic, conventional, fruits, taste, health benefits

\section{Introduction}

The apple is the symbol of convenient fruit available in retail throughout Europe all year round (Konopacka et al. 2010). From 2003 to 2005 the average per capita apple consumption in Europe was $61 \mathrm{~g}$ per day, which is twice as high as per capita consumption worldwide and represents one-quarter of total European fruit consumption (Ceymann et al. 2012). In Estonia the average per capita apple consumption is $34 \mathrm{~g}$ per day. Compared to other most consumed fruits (citrus fruits $30 \mathrm{~g}$ per day, bananas $22 \mathrm{~g}$ per day), apples are the most consumed fruits for Estonians (calculations based on data obtained from Estonian Ministry of Agriculture).

Eating quality is a key factor driving the choices of consumers in fruit consumption (Harker et al. 2003). The most important quality characteristics for apples in different consumer studies have been sweetness, juiciness and crunchiness (Leumann et al. 2004, Jesionkowska et al. 2006, Ikase and Seglina 2008, Konopacka et al. 2010, Symoneaux et al. 2012).

Studies on apple preferences among European consumers have mostly been carried out in Western parts of Europe like Great Britain and Denmark (Jaeger et al. 1998), Switzerland (Leumann et al. 2004, Péneau et al. 2006) and France (Symoneaux et al. 2012). Few studies have been conducted in Eastern European countries like Poland (Jesionkowska et al. 2006) and in Northern Europe in Finland (Seppä et al. 2013). Very few studies have been carried out in former Soviet Union countries like Latvia (Ikase and Seglina 2008).

Apple production in Western Europe went through significant changes in the 1960s, when ancient cultivars were gradually replaced by commercial cultivars and, in Italy for instance, more than $70 \%$ of orchards currently grow only 'Golden Delicious' (Cerutti et al. 2013). In Baltic countries, the situation is different from Western Europe. For instance, in Estonia, the official list of recommended apple cultivars consists of 29 different cultivars originating from Estonia, Finland, Lithuania, Latvia, Russia, Belorussia and Poland (Puuvilja- ja marjakultuuride soovitussortiment 2013). Even though the diversity of locally grown apples is large, the typical commercial cultivars like 'Golden Delicious', 'Jonagold', 'Granny Smith' and others are not cultivated here, since the vegetation period is too short for fruits to ripen. Until 1992, when Estonia regained its independence, these commercial apple cultivars were unknown in the Estonian market. Also, tropical fruits like oranges and bananas were rarely sold and only in larger towns. Since local apples were in reality the only fruit available throughout the year, we may suppose that the fruit consumption habits of people in the European part of former Soviet Union might have been different from those living in neighbouring countries, but in different political regimes. 
It is known that childhood eating habits are important determinants of adult eating behaviour (Woodward et al. 1996). Therefore, we may anticipate that apple preferences of Estonian and other Baltic consumers would differ from those of Western European countries. Furthermore, we hypothesize that differences between generations could also be larger than in other countries, since young people (up to 21 years old) have had the opportunity to eat both domestic and imported apples since childhood, whereas older people ate only domestic apples in childhood.

The current study had three aims:

1. to determine apple preferences of Estonian consumers regarding apple origin, production method and different quality attributes;

2. to determine whether apple preferences of young people raised in a capitalistic system differ from middleaged and older people raised in the Soviet Union.

3. to find out if and how these preferences have changed over five years.

\section{Material and methods}

\section{Elaboration of the questionnaire}

The questionnaire was expected to be completed in 15 minutes or less. A pilot study was carried out with the purpose of assaying the clarity and appropriateness of the questions. Thirty individuals ( 20 students and 10 employees of the Department of Horticulture, Estonian University of Life Sciences) completed the preliminary questionnaire. After this process, some alterations were made to make the questionnaire shorter and to avoid questions which, based on the opinion of the respondents, determined the same things.

The questionnaire consisted of four parts. The aim of the first part was to rate the importance of four different characteristics (appearance, taste, health benefits and price) when choosing an apple. According to relevant literature, taste (Jönsson 2004, Péneau et al. 2006) and appearance (Harker 2001) are among most important selection criteria for apples. The questions about apple health benefits and price were included, since these were expected to affect the motives to buy domestic or imported apples as well as organic or conventional apples (handled in the next part of the questionnaire). The importance of each of the mentioned characteristics was measured separately using a five-point hedonic scale (1 - not important at all... 5 - very important).

The second part of the questionnaire was related to preference for apple origin and production method. Based on the respondent's complaints about repetition in the pilot study, where the preference of domestic, imported, conventional and organic apples was assessed separately, we reformulated the questions as follows: "Do you prefer imported or domestic apples?" The choices of answers were: 1 - definitely imported; 2 - probably imported; 3 - the origin of an apple is not important to me; 4 - probably domestic; 5 - definitely domestic. The question and answers of conventional/organic production were formulated analogously. We followed the principle that the scale of the answers would be symmetrical, the term "apple origin" would be clear (domestic vs. imported) and the scale would allow respondents to express both the direction and strength of their opinion. Additionally, an open-end question were used to allow consumers to specify reasons they prefer domestic or imported apples. In the third part, the aim was to determine respondents' preferences for apple taste and colour. The questions and answers were formulated as follows: "Which kind of apple taste do you prefer?" 1 - sweet; 2 - sour-sweet (sweet is dominating); 3 - sweetish-sour (sour is dominating); 4 - sour. Which colour of apples do you prefer? 1 - red; 2 - yellow; 3 - green; 4 - apple colour is not important to me.

The fourth part of the questionnaire involved demographic characteristics, including questions about gender, year of birth and level of education.

\section{Participant recruitment}

The study was first carried out in 2007 and repeated in 2012. The sample size was set at 300 participants and in order to take into account of any respondent dropout, it was inflated by $20 \%$, resulting 360 initial participants. Respondents were initially recruited among university employees and students and their families originating from all over Estonia. For assuring that gender and age groups would be represented by a sufficient number of con- 
sumers, later people were recruited by personal on-site contacts in Tartu and in two villages in South Estonia. As a selection criterion, participants had to be Estonians in nationality and had to consume apples. Initially, on-line questionnaires were sent to e-mails. In order to include people, who do not use e-mails, printed questionnaires were used. Finally, 89 respondents in 2007 and 140 respondents in 2012 completed the questionnaire on paper. Of the 360 initial participants, 24 respondents in 2007 and 28 in 2012 had missing information on key questions and therefore these respondents were excluded. A final total of 336 respondents in 2007 and 332 respondents in 2012 were included in the analyses (Table 3). Since the group of people having basic education was underrepresented ( 2 and 3\% of the respondents in 2007 and 2012, respectively), this group was merged with the group having secondary education and is referred to as "secondary education" further on in figures, tables and in the text.

Table 1. Descriptive socio-demographic data of the respondents (\%). $N_{2007}=336$ and $N_{2012}=332$.

\begin{tabular}{|c|c|c|c|c|c|c|c|c|c|c|}
\hline \multirow[b]{2}{*}{ Year } & \multicolumn{2}{|c|}{ Gender } & \multicolumn{6}{|c|}{ Age (years) } & \multicolumn{2}{|c|}{ Education } \\
\hline & Male & Female & $16-25$ & $26-30$ & $31-35$ & $36-45$ & $46-55$ & $>55$ & Secondary & Higher \\
\hline 2007 & 46 & 54 & 16 & 19 & 24 & 19 & 10 & 12 & 31 & 69 \\
\hline 2012 & 39 & 61 & 12 & 13 & 19 & 25 & 13 & 18 & 37 & 63 \\
\hline
\end{tabular}

\section{Data analysis}

Collected data was analysed by using Statistica for Windows version 12.0 (StatSoft. Inc., Tulsa, OK, USA). To compare the importance of the different attributes for choice of apples, analyses of variance (ANOVA) were performed on the different attributes in years 2007 and 2012 separately as levels of the within-subject factor. To evaluate possible interactions with demographic characteristics of consumers and apple choice attributes, the importance of each attribute was taken as dependent variable in a one-way ANOVA, with year, gender, age and education as factors. The statistical significance between averages was determined by using the post-hoc Bonferroni test $(p<0.05)$.

Global Chi-square and Chi-square per cell tests were performed to examine differences between demographic groups regarding preferences for domestic or imported, conventional or organic apples, apple taste and colour in different years. Means with the same letter are not significant different according to Fisher Exact Probability Test for a $2 \times 2$ Table $(p<0.05)$.

Principal component analysis (PCA) was performed to describe the structure of the data on importance attributes for choosing an apple, in relation to the study year, respondent's gender, education and age. Analyses were performed on standardised mean data.

\section{Text analysis}

Consumers were grouped according to their apple preferences (imported or domestic apples). As previously described by Symoneaux et al. (2012), respondents' comments were grouped into more structured modalities (Table 3 ) by distinguishing text with the same base and nuance. For instance, claims like "contain less pesticides", "contain less postharvest chemicals"; "are less treated with chemicals", "are safer", "are cleaner" were put together as food safety claims. Altruistic motivations like "I prefer to support domestic farmers"; "I principally buy domestic", "I always prefer Estonian food"; "I support local economy" were grouped together. Answers containing very wide terms like "domestic is better" were left aside.

\section{Results and discussion}

\section{Attributes influencing the choice of apples}

For Estonian consumers, taste was the most important attribute for choosing an apple both in 2007 and 2012 (Fig. 1). The finding is in line with previous studies elsewhere: taste, aroma and freshness were the three most important attributes taken into account by Swiss apple consumers (Péneau et al. 2006). In Sweden too, taste was the most important characteristic affecting the overall impression of apples (Jönsson 2004). In current study, apple health benefits were rated equally important as apple appearance, which is rather unusual compared to earlier studies in other European countries. Jesionkowska et al. (2006) stated that nutritional value of apples was low on the importance list of quality attributes among younger consumers in Poland. Freshness was the primary criterion for apple choice in Switzerland and other aspects such as appearance, nutritional value and organic were of lesser importance (Peneau et al. 2006). 
Apple price was rated fourth in the importance list after apple taste, health benefits and appearance (Fig. 1). However, it was the only characteristic, of which the importance had increased during the period from 2007 to 2012. The economic depression strongly affected Estonians and several issues in the current paper are related to monetary constraints.

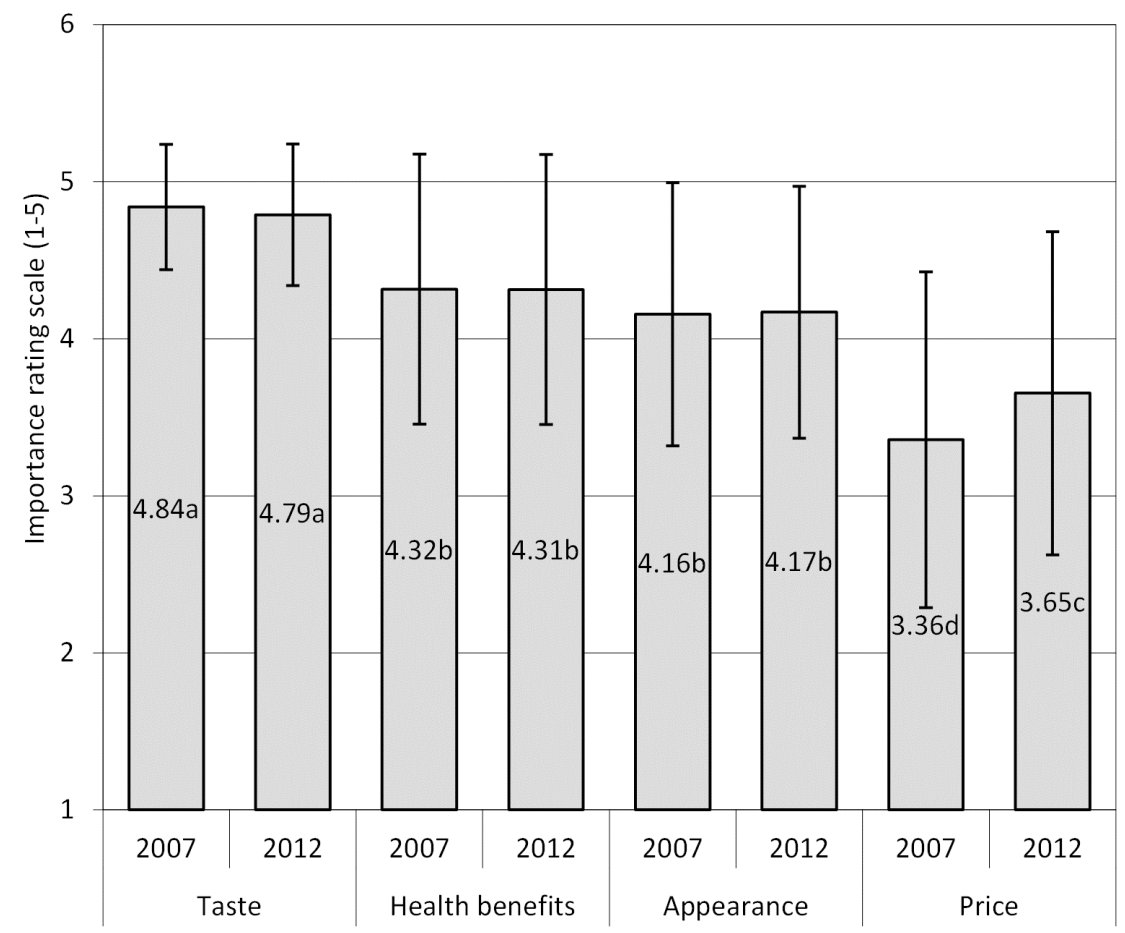

Fig. 1. Importance rating ( 1 - not important at all...5 - very important) of selected attributes for the choice of apples (mean values and standard deviations, $N_{2007}=336$ and $N_{2012}=332$ ). Means with the same letter are not significantly different (Bonferroni, $p<0.05$ ).

\section{Attitudes towards local and imported apples}

The majority of Estonian consumers preferred domestic apples in both years (Table 2). If the number of people who definitely and probably preferred domestic apples were added, the percentages were 91.4 and $81.3 \%$ in 2007 and 2012, respectively. The number of people who were indifferent to the apple origin had increased during the five years.

Socio-demographic characteristics had an impact on apple origin preference. There were more respondents among males, young people ( $<25$ years) and people with secondary education who reported that apple origin is not important for them. The largest difference appeared between people $<25$ years old and people between $46-55$ years of age: while $25.8 \%$ of young people were indifferent towards apple origin, only $2.6 \%$ of respondents $46-55$ years old reported the same. Thus the hypothesis that Estonian consumers under the age 25 might have different apple preferences because of the availability of imported apples since childhood, holds partly true. It has been stated that food preference is an increasing function of exposure frequency: the more frequently a food has been tasted, the better it is liked (Wardle et al. 2003). Cliff et al. (1999) reported that both British Columbian and Nova Scotian consumers preferred a cultivar readily available in their respective communities. The main difference of Estonian people below 25 compared to those in other age groups could be type of apples they have consumed in playschools and schools, not necessarily at home, since parents preferring domestic apples would probably serve those also for their children. Schools and playschools in Estonia buy their foodstuffs from wholesale stores, where imported apples are readily available throughout the year. Another reason could be the higher overall willingness of young people to accept novel cultivars. However, opposite results have also been reported. Jaeger et al. (2003) studied consumers' acceptance of the novel yellow kiwifruit and found that there were more younger (18-30 years) and less older (46+) consumers in the 'dislikers' than 'acceptors' segment. 
Table 2. Preference of domestic or imported apples (\% of the respondents) in 2007 and 2012 among different consumer groups in Estonia. Different letters indicate significant differences $(p<0.05)$ within columns for each characteristic (year, gender, age and education) separately.

\begin{tabular}{|c|c|c|c|c|c|c|}
\hline & & $\begin{array}{l}\text { Definitely } \\
\text { imported }\end{array}$ & $\begin{array}{l}\text { Probably } \\
\text { imported }\end{array}$ & Not important & $\begin{array}{l}\text { Probably } \\
\text { domestic }\end{array}$ & $\begin{array}{l}\text { Definitely } \\
\text { domestic }\end{array}$ \\
\hline \multicolumn{7}{|l|}{ Year } \\
\hline$\chi^{2}=15.403$ & $2007(N=336)$ & $0.0^{\mathrm{a}}$ & $1.2^{\mathrm{a}}$ & $7.4^{\mathrm{b}}$ & $45.3^{\mathrm{a}}$ & $46.1^{\mathrm{a}}$ \\
\hline$p<0.004$ & $2012(N=332)$ & $0.6^{\mathrm{a}}$ & $2.7^{\mathrm{a}}$ & $15.4^{\mathrm{a}}$ & $41.4^{\mathrm{a}}$ & $39.9^{a}$ \\
\hline \multicolumn{7}{|l|}{ Gender } \\
\hline$\chi^{2}=6.003$ & Male $(N=283)$ & $0.4^{\mathrm{a}}$ & $2.5^{\mathrm{a}}$ & $14.5^{\mathrm{a}}$ & $42.7^{\mathrm{a}}$ & $39.9^{\mathrm{a}}$ \\
\hline$p=0.199$ & Female $(N=384)$ & $0.3^{\mathrm{a}}$ & $1.6^{\mathrm{a}}$ & $9.1^{\mathrm{b}}$ & $43.7^{\mathrm{a}}$ & $45.3^{\mathrm{a}}$ \\
\hline \multicolumn{7}{|l|}{ Age } \\
\hline$\chi^{2}=37.680 ;$ & $<25(N=93)$ & $0.0^{\mathrm{a}}$ & $1.1^{\mathrm{a}}$ & $25.8^{\mathrm{a}}$ & $41.9^{\mathrm{a}}$ & $31.2^{\mathrm{b}}$ \\
\hline \multirow[t]{5}{*}{$p<0.01$} & $26-30(N=108)$ & $0.9^{\mathrm{a}}$ & $3.7^{\mathrm{a}}$ & $12.0^{\mathrm{b}}$ & $45.4^{\mathrm{a}}$ & $38.0^{\mathrm{ab}}$ \\
\hline & $31-35(N=144)$ & $0.0^{\mathrm{a}}$ & $1.4^{\mathrm{a}}$ & $9.0^{\mathrm{bc}}$ & $41.7^{\mathrm{a}}$ & $47.9^{\mathrm{a}}$ \\
\hline & $36-45(N=143)$ & $0.7^{\mathrm{a}}$ & $1.4^{\mathrm{a}}$ & $9.8^{\mathrm{bc}}$ & $46.2^{\mathrm{a}}$ & $41.9^{\mathrm{ab}}$ \\
\hline & $46-55(N=76)$ & $0.0^{\mathrm{a}}$ & $2.6^{\mathrm{a}}$ & $2.6^{c}$ & $48.7^{\mathrm{a}}$ & $46.1^{\mathrm{a}}$ \\
\hline & $>55(N=99)$ & $0.0^{\mathrm{a}}$ & $2.0^{\mathrm{a}}$ & $10.1^{b c}$ & $36.4^{\mathrm{a}}$ & $51.5^{\mathrm{a}}$ \\
\hline \multicolumn{7}{|l|}{ Education } \\
\hline$\chi^{2}=15.473$ & $\begin{array}{l}\text { Secondary } \\
(N=226)\end{array}$ & $0.9^{\mathrm{a}}$ & $2.7^{\mathrm{a}}$ & $16.8^{\mathrm{a}}$ & $38.9^{\mathrm{a}}$ & $40.7^{\mathrm{a}}$ \\
\hline$p=0.004$ & Higher $(N=440)$ & $0.0^{\mathrm{a}}$ & $1.6^{\mathrm{a}}$ & $8.6^{\mathrm{b}}$ & $45.7^{\mathrm{a}}$ & $44.1^{\mathrm{a}}$ \\
\hline
\end{tabular}

\section{The main motivations in preferring domestic or imported apples}

The most frequently stated motivation for preferring domestic apples was food safety: domestic apples were believed to contain less pesticide and postharvest chemical residues, therefore being more safe and healthy (Table 3). The second most important reason for preferring domestic apples was better taste. Several respondents stated that taste of domestic cultivars is more variable, whereas imported apples taste "all the same" or are "tasteless". People who preferred imported apples referred mainly to availability throughout the year as the main reason for preference. In 2012, several people stated that they prefer imported apples, because these are cheaper or that they cannot afford domestic apples. We may conclude therefore, that consumers' main motivation to buy domestic apples was related to high expectations regarding product quality; whereas arguments for buying imported apples were more related to convenience. Stolzenbach et al. (2013) have stated that majority of the consumers (>90\%) studied in Denmark had high expectations for the local apple juice; whereas only $38.6 \%$ reported the same for the Mainstream juice.

Altruistic motivations like the principle to buy local food or to support local farmers, ranked third in respondents' text answers in our study.

Table 3. Main motivations (number and \% of statements) for preferring domestic or imported apples in 2007 and 2012 by Estonian consumers (data grouped from respondents' comments by distinguishing modalities with the same base and nuance).

\begin{tabular}{|c|c|c|c|c|}
\hline & \multicolumn{2}{|c|}{ 2007, N=289 } & \multicolumn{2}{|c|}{$2012, N=270$} \\
\hline & No. & $\%$ & No. & $\%$ \\
\hline \multicolumn{5}{|l|}{ Main motivations for preferring domestic apples } \\
\hline $\begin{array}{l}\text { 1. Food safety concerns (domestic apples contain less pre- and postharvest } \\
\text { chemical residues) }\end{array}$ & 113 & 39.1 & 105 & 38.9 \\
\hline 2. Better taste & 76 & 26.3 & 61 & 22.6 \\
\hline 3. Altruistic motivations (wish to support local farmers, local economy etc.) & 28 & 9.7 & 27 & 10.0 \\
\hline \multicolumn{5}{|l|}{ Main motivations for preferring imported apples } \\
\hline 1. Are available all year round & 22 & 7.6 & 14 & 5.2 \\
\hline 2. Are cheaper & - & 0 & 12 & 4.4 \\
\hline
\end{tabular}




\section{Preferences of organic or conventional apples}

Organic farming movement in Estonia began at 1989. From 2002 to 2012 the area of organically certified land has expanded fivefold and in 2012 it constituted around $15.3 \%$ of the total agricultural land in Estonia (Ministry of Agriculture 2012). The demand for organic products is increasing every year; in 2012, 62\% of Estonian consumers stated that they buy organic foods either regularly or occasionally (EMOR 2012).

In our study, in 2007 the majority of respondents stated that they prefer organic apples: $29.6 \%$ would definitely prefer and $48.1 \%$ would probably prefer organic apples (Table 4). The results are in line with the health benefits highly valued by the Estonian consumers. Health benefits have been reported as a main motive for purchasing organic food (Zanoli and Naspetti 2002, Padel and Foster 2005).

Despite the fact that organic apple preference had decreased over the five years from 2007 to $2012,59.6 \%$ of the Estonian consumers would still prefer organic apples (definitely and probably prefer added). Such a high percentage has not reported elsewhere. In Poland, $43 \%$ of adult respondents stated that they would like to buy fruit from environmentally friendly orchards (Jesionkowska et al. 2006). Cross-sectional surveys in the Czech Republic have found that almost one third of consumers wish to buy organic food in the long term (INCOMA 2011 and MZe 2010 ref. Zagata 2012).

The decrease in organic apple preference among Estonians during the period from 2007 to 2012 is most likely related to monetary constraints caused by economic depression. In 2010,46.2\% of Estonian people estimated their economic situation had changed for the worse compared to 2009. In 2012, already half of the households in Estonia said that their economic situation had worsened in comparison with 2011 (ESA 2010 - 2013). Our results are in agreement with Gracia and de Magistris (2008), who stated that income is still limiting the growth of the organic market in Europe.

In current study, women had a higher preference for organic apples compared to men; of the single quality attributes apple health-beneficial properties were also more important to females than males. Thus, our results are in agreement with others who stated that women have stronger health consciousness than men (Duvigneaud et al. 2007).

For young people (below 25 years), apple production method was less important than for people above 31 years old (Table 4). Also in Switzerland, apple consumers between 30 and 60 years old considered organic as being more important, compared to perceptions of young people (below 30 years) (Péneau et al. 2006). In our study, the oldest group (over 55 years old) showed less preference for organic apples compared to people between 31 and 55 years of age. In Denmark, older consumers were more likely to consume organic food than younger consumers (Squires et al. 2001). One reason why older consumers in Estonia do not prefer organic apples, could be related to the higher price of organic products. Since old-age pensioners receive only $35 \%$ of the average wages in Estonia, they cannot often afford price-premium food.

\section{Consumer preferences of apple taste}

The majority of Estonian consumers preferred sour-sweet apples and this preference had not changed from 2007 to 2012 . Only 19\% of consumers in 2007 and $16.4 \%$ in 2012 stated that they prefer sweet apples (Table 5). Fifteen years ago it was noted that most apple consumers' preference vectors were lying in the direction positively associated with firmness, juiciness and sweetness (Jaeger et al. 1998). Ethnicity is reported to strongly affect apple preferences. Cliff et al. (2014) demonstrated that $88 \%$ of consumers of Asian ethnicity identified themselves as sweet apple eaters, while only $55 \%$ of consumers of European ethnicity reported the same. Recently some doubts have been raised regarding consumers' expectations for sweeter fruit in Europe; however, it is still regarded as the leading trend (Konopacka et al. 2010). As reported by Symoneaux et al. (2012), the most recurrent apple likes mentioned by the consumers were crunchy, juicy and sweet. Recent study carried out in different European countries indicated that the best accepted apple varieties were characterized by firmness, sweetness and an average or lower than average acidity (Bonany et al. 2013). On the other hand, Gibalova et al. (2012) have reported that Norwegian consumers appreciate the sourer apple cultivars grown locally. Also in Finland, the medium sour apple 'Aroma' had the highest liking score, whereas sweet 'Pekka' was less liked (Seppä et al. 2013). However, in the ideal apple questionnaire Finnish consumers rated sweetness higher than sourness (Seppä 2014). The author has argued that Finns as a Northern people are used to quite sour apples and thus, sweet apples means a completely different concept in Finland than for example in South Europe. Also in Estonia, the titratable acidity in the locally well-known and liked apples is quite high: 0.77 and $0.62 \%$ for 'Liivi kuldrenett' and 'Krameri tuviõun', respective- 
ly (Moor et al. 2005). Well-known imported cultivars 'Jonagold' and 'Golden Delicious', have reported titratable acidity content of 0.39 and $0.38 \%$, respectively (Wu et al. 2007), which is notably lower. Harker et al. (2002) investigated the relationship between objective and sensory measurements of apple taste and concluded that differences in titratable acidity as low as $0.08 \%$ between apples could evoke a perceived acid taste response for the average panellist.

Table 4. Preference of conventional or organic apples (\% of the respondents) in different years and among different consumer groups in Estonia. Different letters indicate significant differences $(p<0.05)$ within columns for each characteristic (year, gender, age and education) separately.

\begin{tabular}{|c|c|c|c|c|c|c|}
\hline & & $\begin{array}{c}\text { Definitely } \\
\text { conventional }\end{array}$ & $\begin{array}{c}\text { Probably } \\
\text { conventional }\end{array}$ & Not important & $\begin{array}{c}\text { Probably } \\
\text { organic }\end{array}$ & $\begin{array}{c}\text { Definitely } \\
\text { organic }\end{array}$ \\
\hline \multicolumn{7}{|l|}{ Year } \\
\hline$\chi^{2}=26.987$ & $2007(N=335)$ & $2.1^{\mathrm{a}}$ & $7.8^{\mathrm{b}}$ & $12.5^{\mathrm{b}}$ & $48.1^{\mathrm{a}}$ & $29.5^{\mathrm{a}}$ \\
\hline$p<0.000$ & $2012(N=329)$ & $1.8^{\mathrm{a}}$ & $15.8^{\mathrm{a}}$ & $22.8^{\mathrm{a}}$ & $37.1^{\mathrm{b}}$ & $22.5^{\mathrm{b}}$ \\
\hline \multicolumn{7}{|l|}{ Gender } \\
\hline$\chi^{2}=8.636$ & Male $(N=283)$ & $3.2^{\mathrm{a}}$ & $13.4^{\mathrm{a}}$ & $19.8^{\mathrm{a}}$ & $38.2^{\mathrm{b}}$ & $25.4^{\mathrm{a}}$ \\
\hline$p=0.071$ & $\begin{array}{l}\text { Female } \\
(N=381)\end{array}$ & $1.0^{\mathrm{a}}$ & $10.5^{\mathrm{a}}$ & $16.0^{\mathrm{a}}$ & $45.9^{\mathrm{a}}$ & $26.5^{\mathrm{a}}$ \\
\hline \multicolumn{7}{|l|}{ Age } \\
\hline$\chi^{2}=48.208$ & $<25(N=93)$ & $3.2^{\mathrm{a}}$ & $9.7^{\mathrm{b}}$ & $28.0^{\mathrm{a}}$ & $37.6^{\mathrm{ab}}$ & $21.5^{\mathrm{a}}$ \\
\hline \multirow[t]{5}{*}{$p<0.001$} & $26-30(N=108)$ & $0.0^{\mathrm{a}}$ & $6.5^{\mathrm{b}}$ & $24.1^{\mathrm{ab}}$ & $40.7^{\mathrm{ab}}$ & $28.7^{\mathrm{a}}$ \\
\hline & $31-35(N=144)$ & $0.7^{\mathrm{a}}$ & $6.9^{\mathrm{b}}$ & $16.7^{\mathrm{bc}}$ & $46.5^{\mathrm{a}}$ & $29.2^{\mathrm{a}}$ \\
\hline & $36-45(N=142)$ & $2.1^{\mathrm{a}}$ & $14.1^{\mathrm{ab}}$ & $12.7^{c}$ & $50.0^{\mathrm{a}}$ & $21.1^{\mathrm{a}}$ \\
\hline & $46-55(N=75)$ & $1.3^{\mathrm{a}}$ & $13.3^{\mathrm{ab}}$ & $14.7^{\mathrm{bc}}$ & $46.7^{\mathrm{a}}$ & $24.0^{\mathrm{a}}$ \\
\hline & $>55(N=98)$ & $5.1^{\mathrm{a}}$ & $22.5^{\mathrm{a}}$ & $12.2^{\mathrm{c}}$ & $29.6^{b}$ & $30.6^{\mathrm{a}}$ \\
\hline \multicolumn{7}{|l|}{ Education } \\
\hline$\chi^{2}=28.994$ & $\begin{array}{l}\text { Secondary } \\
(N=226)\end{array}$ & $4.0^{\mathrm{a}}$ & $10.2^{\mathrm{a}}$ & $21.7^{\mathrm{a}}$ & $30.9^{b}$ & $33.2^{\mathrm{a}}$ \\
\hline$p<0.000$ & Higher $(N=437)$ & $0.9^{\mathrm{a}}$ & $12.6^{\mathrm{a}}$ & $15.6^{\mathrm{a}}$ & $48.7^{\mathrm{a}}$ & $22.2^{\mathrm{b}}$ \\
\hline
\end{tabular}

Table 5. Apple taste ${ }^{a}$ preferences (\% of the respondents) of Estonian consumers depending on the year, consumer gender, age and education. Different letters indicate significant differences $(p<0.05)$ within columns for each characteristic (year, gender, age and education) separately.

\begin{tabular}{|c|c|c|c|c|c|}
\hline & & Sour & Sweetish-sour & Sour-sweet & Sweet \\
\hline \multicolumn{6}{|l|}{ Year } \\
\hline$\chi^{2}=1.895$ & $2007(N=336)$ & $0.6^{\mathrm{a}}$ & $13.1^{\mathrm{a}}$ & $67.3^{\mathrm{a}}$ & $19.0^{\mathrm{a}}$ \\
\hline$p=0.594$ & $2012(N=324)$ & $0.9^{\mathrm{a}}$ & $11.1^{\mathrm{a}}$ & $71.6^{\mathrm{a}}$ & $16.4^{\mathrm{a}}$ \\
\hline \multicolumn{6}{|l|}{ Gender } \\
\hline$\chi^{2}=1.631$ & Male $(\mathrm{N}=281)$ & $0.7^{\mathrm{a}}$ & $13.9^{\mathrm{a}}$ & $67.3^{\mathrm{a}}$ & $18.1^{\mathrm{a}}$ \\
\hline$p=0.652$ & Female $(\mathrm{N}=379)$ & $0.8^{\mathrm{a}}$ & $10.8^{\mathrm{a}}$ & $71.0^{\mathrm{a}}$ & $17.4^{\mathrm{a}}$ \\
\hline \multicolumn{6}{|l|}{ Age } \\
\hline$\chi^{2}=36.267$ & $<25(N=93)$ & $2.2^{\mathrm{a}}$ & $8.6^{\mathrm{bc}}$ & $68.8^{\mathrm{ab}}$ & $20.4^{\mathrm{ab}}$ \\
\hline \multirow[t]{5}{*}{$p<0.002$} & $26-30(N=107)$ & $0.0^{\mathrm{a}}$ & $13.1^{\mathrm{ab}}$ & $57.9^{b}$ & $29.0^{\mathrm{a}}$ \\
\hline & $31-35(N=142)$ & $2.1^{\mathrm{a}}$ & $12.7^{\mathrm{ab}}$ & $67.6^{\mathrm{b}}$ & $17.6^{\mathrm{bc}}$ \\
\hline & $36-45(N=141)$ & $0.0^{\mathrm{a}}$ & $5.7^{c}$ & $78.7^{\mathrm{a}}$ & $15.6^{\mathrm{bc}}$ \\
\hline & $46-55(N=75)$ & $0.0^{\mathrm{a}}$ & $16.0^{\mathrm{ab}}$ & $70.7^{\mathrm{ab}}$ & $13.3^{\mathrm{bc}}$ \\
\hline & $>55(\mathrm{~N}=98)$ & $0.0^{\mathrm{a}}$ & $19.4^{\mathrm{a}}$ & $70.4^{\mathrm{ab}}$ & $10.2^{\mathrm{c}}$ \\
\hline \multicolumn{6}{|l|}{ Education } \\
\hline$\chi^{2}=13.659 ;$ & Secondary ( $N=222)$ & $1.3^{\mathrm{a}}$ & $12.2^{\mathrm{a}}$ & $61.7^{\mathrm{b}}$ & $24.8^{\mathrm{a}}$ \\
\hline$p<0.004$ & Higher $(\mathrm{N}=437)$ & $0.5^{\mathrm{a}}$ & $12.1^{\mathrm{a}}$ & $73.2^{\mathrm{a}}$ & $14.2^{\mathrm{b}}$ \\
\hline
\end{tabular}

a In order to avoid confusion, it was explained in questionnaire that sweetish-sour apple means that the sour taste is dominant and in soursweet apples sweet taste is dominant. 
Soluble solids concentration (SSC) has been shown to be the best predictor of difference in taste when apple SSC differs by more than $1^{\circ}$ Brix (Harker et al. 2002). Nordic apple cultivars tend to have lower SSC compared to wellknown commercial cultivars. It has been reported that SSC of 8 apple cultivars grown in Finland range from 10.7 to 11.7 ( Dris 1998). 'Golden Delicious' and 'Jonagold' have SSC 13.4 and $12.3^{\circ}$ Brix, respectively (Wu et al. 2007).

The taste preferences of the consumers in our study were different between age groups: people over 55 years of age tended to prefer more sour apples than other groups. There is evidence that human chemosensory abilities decrease with age, since the number of receptors decline, and some lose their efficiency (Schiffman 1986). It has been reported that sweet taste acuity may be most susceptible to deterioration with age (Sanders et al. 2002).

\section{Consumer preferences of apple colour}

Apple colour was not important characteristic for the majority of Estonian consumers and colour preference had not changed during five years: 66.0 and $68.9 \%$ of the consumers were indifferent towards apple colour in 2007 and 2012, respectively (Table 6). In both years, $22 \%$ of the respondents indicated preference for red apples, 7.3 to $10.1 \%$ for yellow apples and negligible amount of the consumers preferred green apples. Similar results have been reported for Finland: only 20 among 122 respondents wanted red apples (Seppä 2014). The red apple preference was only slightly higher than the green apple preference (Seppä et al. 2013). In contrast, preference for red apples has been reported in several European countries. In Poland, more than 50\% of respondents appreciated red apples (Jesionkowska et al. 2006). In Switzerland, young people preferred red apples (Leumann et al. 2004). We assume that the reason why Estonians do not prefer red apples, is related to the appearance of the locally grown apples: only 3 cultivars out of 29 in the recommended cultivar list can be characterised as fully red. Also, no distinct preferences were found for apple colour among Latvian consumers (Ikase and Seglina 2008).

Table 6. Apple colour preferences of Estonian consumers (\% of the respondents) depending on the year, consumer gender, age and education. Different letters indicate significant differences $(p<0.05)$ within columns for each characteristic (year, gender, age and education) separately.

\begin{tabular}{|c|c|c|c|c|c|}
\hline & & Red & Yellow & Green & Not important \\
\hline \multicolumn{6}{|l|}{ Year } \\
\hline$\chi^{2}=1.734$ & $2007(N=335)$ & $22.1^{\mathrm{a}}$ & $10.1^{\mathrm{a}}$ & $1.8^{\mathrm{a}}$ & $66.0^{\mathrm{a}}$ \\
\hline$P=0.629$ & $2012(N=328)$ & $22.0^{\mathrm{a}}$ & $7.3^{\mathrm{a}}$ & $1.8^{\mathrm{a}}$ & $68.9^{a}$ \\
\hline \multicolumn{6}{|l|}{ Gender } \\
\hline$\chi^{2}=14.864 ;$ & Male $(\mathrm{N}=282)$ & $26.2^{\mathrm{a}}$ & $12.1^{\mathrm{a}}$ & $2.1^{\mathrm{a}}$ & $59.6^{b}$ \\
\hline$p<0.002$ & Female $(\mathrm{N}=381)$ & $18.9^{b}$ & $6.3^{b}$ & $1.6^{\mathrm{a}}$ & $73.2^{\mathrm{a}}$ \\
\hline \multicolumn{6}{|l|}{ Age } \\
\hline$\chi^{2}=26.238 ;$ & $<25(\mathrm{~N}=91)$ & $26.4^{\mathrm{ab}}$ & $15.4^{\mathrm{a}}$ & $2.2^{\mathrm{a}}$ & $56.0^{\mathrm{b}}$ \\
\hline \multirow[t]{5}{*}{$p=0.036$} & $26-30(N=107)$ & $19.6^{b}$ & $13.1^{\mathrm{a}}$ & $1.9^{\mathrm{a}}$ & $65.4^{\mathrm{ab}}$ \\
\hline & $31-35(N=144)$ & $16.0^{\mathrm{b}}$ & $8.3^{\mathrm{ab}}$ & $2.1^{\mathrm{a}}$ & $73.6^{\mathrm{a}}$ \\
\hline & $36-45(\mathrm{~N}=143)$ & $19.6^{b}$ & $5.6^{\mathrm{b}}$ & $2.1^{\mathrm{a}}$ & $72.7^{\mathrm{a}}$ \\
\hline & $46-55(N=76)$ & $21.1^{\mathrm{ab}}$ & $3.9^{\mathrm{b}}$ & $1.3^{\mathrm{a}}$ & $73.7^{\mathrm{a}}$ \\
\hline & $>55(N=98)$ & $33.7^{\mathrm{a}}$ & $7.1^{\mathrm{ab}}$ & $1.0^{\mathrm{a}}$ & $58.2^{\mathrm{b}}$ \\
\hline \multicolumn{6}{|l|}{ Education } \\
\hline$\chi^{2}=4.429$ & Secondary $(N=224)$ & $24.5^{\mathrm{a}}$ & $10.3^{\mathrm{a}}$ & $2.7^{\mathrm{a}}$ & $62.5^{b}$ \\
\hline$p=0.219$ & Higher $(\mathrm{N}=438)$ & $20.8^{a}$ & $8.0^{\mathrm{a}}$ & $1.3^{\mathrm{a}}$ & $69.9^{\mathrm{a}}$ \\
\hline
\end{tabular}

\section{Results of the principal component analysis (PCA)}

The first two components explained $43.6 \%$ of the total variation (Fig. 2). Two groups of variables could be clearly distinguished: apple credence attributes (organic, domestic, health benefits), had the largest loading on PC1 and apple sensory attributes (sweetness, appearance, taste) on PC2. Credence attributes were relatively more important for highly educated people, females and for people at the age of 46-55 years. The interest towards sensory attributes was higher among women and people at the age of $<25$ years (Fig.2). 


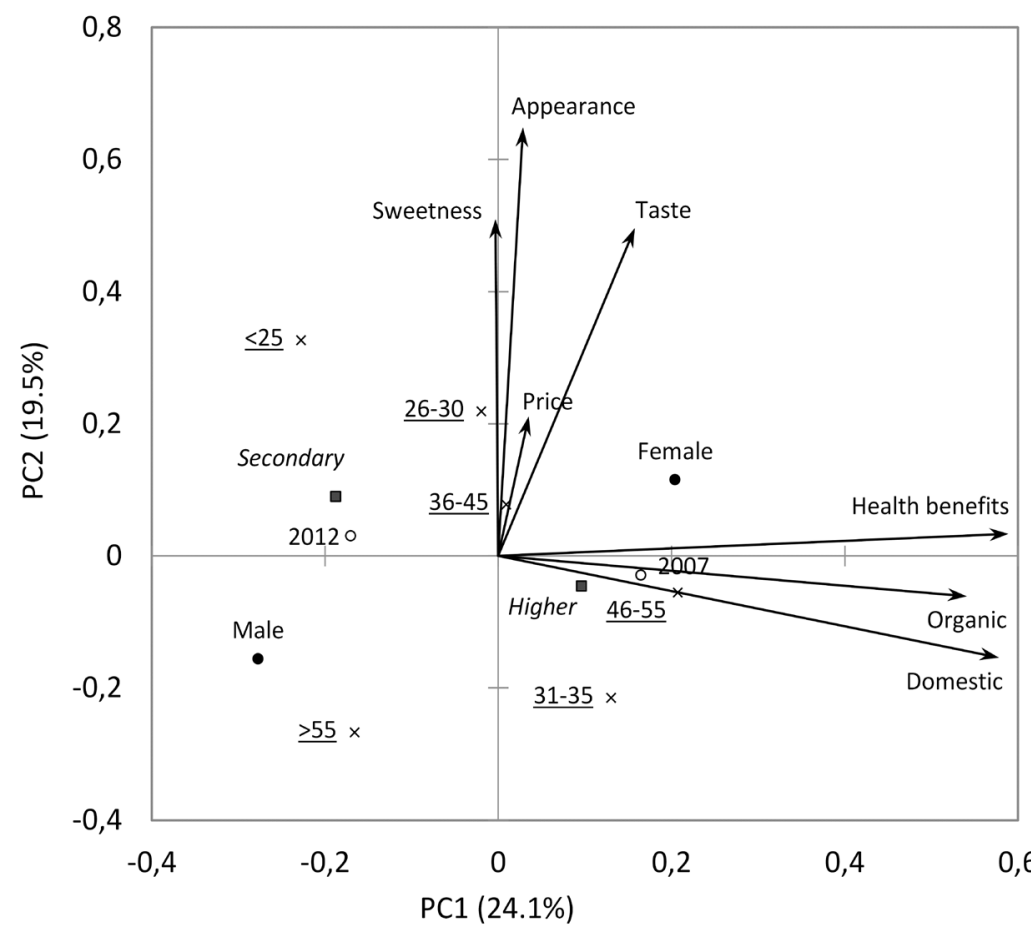

Fig. 2. Principal component analysis plot based on importance of attributes for choosing an apple, and the projection of research year, respondent's gender, education and age (underlined).

Third principal component (PC3) explained $15.6 \%$ of overall variability, had strong positive correlation with price and intermediate negative correlation with taste (data not shown). PC3 had higher values among older respondents and in year 2012. Thus, older people are more price sensitive; also in 2012 price was more important to consumers than in 2007.

In an earlier study, European females were reported to give higher importance to texture, flavour and taste at consumption than men (Ragaert et al. 2004). Padilla Bravo et al. (2013) concluded that consumers more motivated by regional aspects and food specialties tend to show more positive attitudes towards organic food and buy it more frequently. In USA, also females with better education, had a higher "Natural" oriented factor, meaning that organic and locally grown food were of greater importance for them compared to others (Bellows et al. 2010). Also in Denmark, the education level of the consumer, higher income and age significantly increased the probability of being a heavy consumer of organic food (Millock et al. 2004).

Estonians are generally well-educated: the percentage of persons with upper secondary or tertiary education in Estonia was $88.9 \%$ in 2011, while the EU 27 average was 73.3\% (Eurostat 2013). It could partly explain high healthconsciousness and preference for organic apples among Estonian consumers.

\section{Conclusions}

The Estonian market has been open for imported apples for about 20 years; before 1992 only locally produced apples were available. The current study revealed that the preference for domestic apples in Estonia is still very strong. However, young people raised in a capitalistic system were significantly more indifferent towards apple origin compared to middle-aged and older people, which might be partially attributed to the type of apples they have consumed in playschools and schools, not necessarily at home, since parents preferring domestic apples would probably serve those also for children. Schools and playschools in Estonia are supplied with imported apples, which are readily available throughout the year. Therefore the effect of school food on fruit consumption habits would be possible research target in future.

Estonian consumers did not confirm the general opinion that people prefer red and sweet apples: for the majority of the respondents, apple colour was not important and less than $1 / 5$ of the consumers stated that they prefer sweet apples. After taste, apple health benefits were rated equally important as apple appearance, which contradicts earlier studies in other parts of Europe. Therefore, variable taste, food safety and apple health benefits should be considered in product information when marketing apples in Estonia. 
Over the five year period surveyed, the preference for domestic and organic apples had decreased, most probably due to the economic depression and therefore limited possibility to pay a premium price for organic or domestic apples. Consumers' taste and colour preference of apples had remained unchanged during these five years. In future research it would be interesting to conduct a similar investigation in the other European parts of the former Soviet Union in order to determine if these Estonian preferences for apples apply also to larger markets (e.g. Riga in Latvia and Saint Petersburg in Russia).

\section{Acknowledgements}

The current research was supported by Enterprise Estonia (in 2007) and Estonian Science Foundation target-financed research project SF0170057s09. Assistance of statistician ass. prof. Tanel Kaart is greatly appreciated. Authors are also grateful to ass. prof. Jacquie van der Waals for English editing.

\section{References}

Bellows, A.C., Alcaraz, G. \& Hallman, W.K. 2010. Gender and food, a study of attitudes in the USA towards organic, local, U.S. grown, and GM-free foods. Appetite 55: 540-550.

Bonany, J., Buehler, A., Carbó, J., Codarin, S., Donati, F., Echeverria, G., Egger, S., Guerra, W., Hilaire, C., Höller, I., Iglesias, I., Jesionkowska, K., Konopacka, D., Kruczynska, D., Martinelli, A., Pitiot, C., Sansavini, S., Stehr, R. \& Schoorl, F. 2013. Consumer eating quality acceptance of new apple varieties in different European countries. Food Quality and Preference 30: 250-259.

Cerutti, A.K., Bruun, S, Donno, D., Beccaro, G.L. \& Bounous, G. 2013. Environmental sustainability of traditional foods: the case of ancient apple cultivars in Northern Italy assessed by multifunctional LCA. Journal of Cleaner Production 52: 245-252.

Ceymann, M., Arrigoni, E., Scharer, H., Nising, A.B. \& Hurrell, R.F. 2012. Identification of apples rich in health-promoting flavan3-ols and phenolic acids by measuring the polyphenol profile. Journal of Food Composition and Analysis 26: 128-135.

Cliff, M.A., Sanford, K. \& Johnston, E. 1999. Evaluation of hedonic scores and R-indices for visual, flavour and texture preferences of apple cultivars by British Columbian and Nova Scotian consumers. Canadian Journal of Plant Science 79: 395-399.

Cliff, M.A., Stanich, K. \& Hampson, C. 2014. Consumer research explores acceptability of a new Canadian apple - Salish ${ }^{\mathrm{TM}}$. Canadian Journal of Plant Science 94: 99-108.

Dris, R. 1998. Effect of postharvest calcium treatments on postharvest quality of apples grown in Finland. Doc. thesis. Helsinki: University of Helsinki. 111 p.

Duvigneaud, N., Wijndaele, K., Matton, L., Philippaerts, R., Lefevre, J., Thomis, M., Delecluse, C. \& Duquet, W. 2007. Dietary factors associated with obesity indicators and level of sports participation in Flemish adults: a cross-sectional study. Nutrition Journal 6: 26.

EMOR 2012. Eesti elanike toidukaupade ostueelistused ja hoiakud 2012 (Estonian residents' Grocery shopping preferences and attitudes in 2012). In Estonian.

ESA. 2011, 2012, 2013. Statistical Yearbook of Estonia, 2011, 2012, 2013. Eesti Statistika Aastaraamat. Available from: http:// www.stat.ee/publications Accessed 05 March 2014.

Eurostat, 2013. Upper secondary or tertiary educational attainment, age group 25-64 by sex. http://epp.eurostat.ec.europa.eu/ tgm/table.do?tab=table\&plugin=0\&language=en\&pcode=tps00065 Accessed 05 March 2014.

Gibalova, A., Vangdal, E. \& Leufven, A. 2012. Factors affecting storability in apples. Acta Horticulturae 945: 369-374.

Gracia, A. \& de Magistris, T. 2008. The demand for organic foods in the South of Italy: A discrete choice model. Food Policy 33 : 386-396.

Harker, F.R., Gunson, F.A. \& Jaeger, S.R. 2003. The case for fruit quality: An interpretive review of consumer attitudes, and preferences for apples. Postharvest Biology and Technology 28: 333-347.

Harker, F.R., Marsh, K.B., Young, H., Murray, S.H., Gunson, F.A. \& Walker, S.B. 2002. Sensory interpretations of instrumental measurements 2: sweet and acid taste of apple fruit. Postharvest Biology and Technology 24: 241-250.

Harker, R. 2001. Consumer response to apples. In: Proceedings of the Washington Tree Fruit Postharvest Conference. WSU-TFREC Postharvest Information Network. http://postharvest.tfrec.wsu.edu/PC2001V.pdf Accessed 23 May 2014.

Ikase, L. \& Seglina, D. 2008. Fruit quality assessment of apple cultivars. Proceedings of international scientific conference "Sustainable Fruit Growing: From Plant to Product", p. 54-64. Available from: http://www.lvai.lv/pdf/Raksti-viss-drukai.pdf Accessed 23 May 2014.

INCOMA 2011. Shopping Monitor 2011. Komplexní analýza nákupního chování/ Shopping Monitor 2011. Complex analysis of shopping behavior. Praha: Incoma GfK, s.r.o.

Jaeger, S.R., Andani, Z., Wakeling, I.N. \& MacFie, H.J.H. 1998. Consumer preferences for fresh and aged apples: a cross-cultural comparison. Food Quality and Preference 9: 355-366.

Jaeger, S.R., Rossiter, K.L., Wismer, W.V. \& Harker, F.R. 2003. Consumer-driven product development in the kiwifruit industry. Food Quality and Preference 14: 187-198.

Jesionkowska, K., Konopacka, D. \& Płocharski, W. 2006. The quality of apples - preferences among consumers from Skierniewice, Poland. Journal of Fruit and Ornamental Plant Research 14: 173-182. 
Jönsson, A.H. 2004. Consumer evaluation of scab resistant apple cultivars. Acta Horticulturae 663: 875-878.

Konopacka, D., Jesionkowska, K., Kruczyńska, D., Stehr, R., Schoorl, F., Buehler, A., Egger, S., Codarin, S., Hilaire, C., Höller, I., Guerra, W., Liverani, A., Donati, F., Sansavini, S., Martinelli, A., Petiot, C., Carbó, J., Echeverria, G., Iglesias, I. \& Bonany, J. 2010. Apple and peach consumption habits across European countries. Appetite 55: 478-483.

Leumann, R., Kellerhals, M., Schärer, H. \& Höhn, E. 2004. Konsumentest von Diwa", Elstar und Idared mit Befragung zum Apfelkonsum. Schweizer Zeitschrift für Obst- und Weinbau 21: 6-9.

Millock, K., Wier, M. \& Andersen, L.M. 2004. Consumer demand for organic foods - attitudes, values and purchasing behaviour. Paper at: 13th annual EAERE Conference, Budapest, June 2004. Available from: http://orgprints.org/4754/ Accessed: 12 July 2013. Ministry of Agriculture 2012. Organic farming in Estonia. Tallinn, $51 \mathrm{p}$.

Moor, U., Põldma, P., Karp, K., Asafova, L. \& Pae, A. 2005. Influence of preharvest calcium treatments on postharvest quality of some Estonian apple cultivars. Acta Horticulturae 682: 1041-1048.

MZe 2010. Ekologické zemědělství a biopotraviny. Závěrečná zpráva z exkluzivního výzkumu pro Ogilvy \& Mather/Organic agriculture and organic food. Final report from the exclusive survey for the Ogilvy \& Mather. [online]. Retrieved from: On January 2nd 2011.

Padel, S. \& Foster, C. 2005. Exploring the gap between attitudes and behaviour: Understanding why consumers buy or do not buy organic food. British Food Journal 107: 606-625.

Padilla Bravo, C., Cordts, A., Schulze, B. \& Spiller, A. 2013. Assessing determinants of organic food consumption using data from the German National Survey II. Food Quality and Preference 28: 60-70.

Péneau, S., Hoehn, E., Roth, H.-R., Escher, F. \& Nuessli, J. 2006. Importance and consumer perception of freshness of apples. Food Quality and Preference 17: 9-19.

Puuvilja- ja marjakultuuride soovitussortiment 2013 (in Estonian). Recommended cultivars of fruit and berry crops. Available from: http://www.aiandusliit.ee/puuvilja-ja-marjakultuuride-soovitussortiment/ Accessed: 05 January 2014.

Ragaert, P., Verbeke, W., Devlieghere, F. \& Debevere, J. 2004. Consumer perception and choice of minimally processed vegetables and packaged fruits. Food Quality and Preference 15: 259-270.

Sanders, O.G., Ayers, J.V. \& Oakes, S. 2002. Taste acuity in the elderly: the impact of the threshold, age gender, medication, health and dental problems. Journal of Sensory Studies 17: 89-104.

Schiffman, S.S. 1986. Age-related changes in taste and smell and their possible causes. In: Meiselman, L. \& Livlin, R.S. (Eds.). Clinical measurement of taste and smell. New York: MacMillan. p. 326-342.

Seppä, L. 2014. Domestic apple cultivars. Sensory descriptions and consumer responses. Doc. thesis. Helsinki: University of Helsinki. 90 p.

Seppä, L., Railio, J., Vehkalahti, K., Tahvonen, R. \& Tuorila, H. 2013. Hedonic responses and individual definitions of an ideal apple as predictors of choice. Journal of Sensory Studies 28: 346-357.

Squires, L., Juric, B. \& Cornwell, T.B. 2001. Level of market development and intensity of organic food consumption: cross-cultural study of Danish and New Zealand consumers. Journal of Consumer Marketing 18: 392-409.

Stolzenbach, S., Bredie, W.L.P., Christensen, R.H.B. \& Byrne, D.V. 2013. Impact of product information and repeated exposure on consumer liking, sensory perception and concept associations of local apple juice. Food Research International 52: 91-98.

Symoneaux, R., Galmarini, M.V. \& Mehinagic, E. 2012. Comment analysis of consumer's likes and dislikes as an alternative tool to preference mapping. A case study on apples. Food Quality and Preference 24: 59-66.

Wardle, J., Cooke, L.J., Gibson, E.L., Sapochnik, M., Sheiham, A. \& Lawson, M. 2003. Increasing children's acceptance of vegetables; a randomized trial of parent-led exposure. Appetite 40: 155-162.

Woodward, D.R., Boon, J.A., Cumming, F.J., Ball, P.J., Williams, H.M. \& Hornsby, H. 1996. Adolescents' reported usage of selected foods in relation to their perceptions and social norms for those foods. Appetite 27: 109-117.

Wu, J., Gao, H., Zhao, L., Liao, X. jun., Chen, F., Wang, Z. \& Hu, X. 2007. Chemical compositional characterization of some apple cultivars. Food Chemistry 103: 88-93.

Zagata, L. 2012. Consumers' beliefs and behavioural intentions towards organic food. Evidence from the Czech Republic. Appetite 59: 81-89.

Zanoli, R. \& Naspetti, S. 2002. Consumer motivations in the purchase of organic food. A means-end approach. British Food Journal 104: 643-653. 